\title{
Resistance of mechanically densified and thermally post-treated pine sapwood to wood decay fungi
}

\author{
Hüseyin Pelit ${ }^{1} \cdot$ Mesut Yalçın $^{2}$
}

Received: 28 March 2017 / Accepted: 2 June 2017/Published online: 28 June 2017

(C) The Japan Wood Research Society 2017

\begin{abstract}
This paper evaluated the density and biological resistance of pinewood samples modified with thermomechanical densification and thermal post-treatment. The samples were densified with 20 and $40 \%$ compression ratios at either 110 or $150{ }^{\circ} \mathrm{C}$. The thermal post-treatment was then applied to the pine samples at 185 and $212{ }^{\circ} \mathrm{C}$ for $2 \mathrm{~h}$. These samples were exposed to white-rot (Trametes versicolor) and brown-rot (Coniophora puteana) fungi for twelve weeks and the resulting mass loss was determined. In the densified samples, the effects of the compression ratio on $T$. versicolor-initiated mass loss and of the compression temperature on C. puteana-initiated mass loss were found to be significant. The mass loss was less in the samples compressed at $150{ }^{\circ} \mathrm{C}$ with the $40 \%$ ratio, while the highest mass loss was observed in the undensified samples. In the thermally post-treated samples, the resistance to both decay fungi was significantly increased with the increase of the treatment temperature. The mass loss in the thermally post-treated samples at $212{ }^{\circ} \mathrm{C}$ after $T$. versicolor and C. puteana fungi testing was reduced by 73 and $67 \%$, respectively. However, the effect of the densification processes on decay resistance in the thermally post-treated samples was insignificant.
\end{abstract}

Keywords Densification - Thermal post-treatment $\cdot$ Pine wood $\cdot$ Biological resistance

Hüseyin Pelit

huseyinpelit@duzce.edu.tr

1 Department of Wood Products Industrial Engineering, Faculty of Technology, Duzce University, Konuralp, 81620 Düzce, Turkey

2 Department of Forest Products Engineering, Faculty of Forestry, Duzce University, Konuralp, 81620 Düzce, Turkey

\section{Introduction}

Wood is a sustainable, non-toxic and recyclable natural material having high strength and an aesthetic appearance. Because of these superior characteristics, wood is popular and widely used in many areas. However, under suitable climatic conditions, wood is easily biodegradable and vulnerable to various organisms like fungi and insects $[1,2]$. A number of methods have been developed to protect wooden materials against these biological factors. Chemical impregnation of wood is one of the most important of these. Nonetheless, the use of many of these chemical preservatives has been restricted in various European countries due to the environmental concerns $[3,4]$. As a result, a number of new modification methods have recently been developed for wood protection.

Thermal treatment is a wood improvement and preservation process against biotic and abiotic factors [5]. Although the mechanical properties of wood are affected by the thermal treatment process [6], it provides some important improvements in wood properties including dimensional stability, hygroscopicity, and decay resistance [7-9]. Thermal treatments affect chemical factors required for the growth of fungi such as nitrogen, vitamins, minor metals and mineral elements [10]. With thermal treatment, wood becomes more resistant to fungi due to chemical modifications of the wood components of cellulose, hemicellulose, and lignin [11-13]. On the other hand, thermal treatments reduce most of the mechanical strength properties of wood [14-17]. As a result of these undesired disadvantages, extensive commercial utilisation of thermally treated wood has been limited [18]. Through the modification of densification, many of the physical and mechanical properties of wood can be improved. The modification process of densification in wood is usually 
performed by compressing wood in a transverse direction. Additionally, wood material can be densified via the impregnation of various chemicals into the cell cavities of the wood.

The main problem occurring in wood densification via mechanical compression is that the compressed wood becomes dimensionally unstable [19-22]. Thus, when compressed/densified wood is exposed to high relative humidity or soaked in water, it returns to nearly its original pre-compression dimensions [23-26]. With the intent of providing dimensional stability to mechanically compressed wood, various densification processes, such as thermo-hygro-mechanical (THM) and viscoelastic thermal compression (VTC), in which steam and heat are combined, have been developed [27, 28]. Moreover, dimensional stability has been enhanced using thermal posttreatments applied to the compressed wood at a high temperature [26, 29-31].

In light of the knowledge available in the literature, the purpose of this study was to determine the decay resistance of pine sapwood samples modified with the combination of mechanical densification and thermal post-treatment against white-rot (Trametes versicolor) and brown-rot (Coniophora puteana) fungi. In addition, the density variations in the densified and thermally post-treated pine samples were also analysed.

\section{Materials and methods}

\section{Wood material}

For this study, randomly selected Scots pine (Pinus sylvestris $\mathrm{L}$.) wood, from a timber company in Düzce, Turkey, was used. The pine samples were cut in rough sizes from sapwood, in accordance with the study methodology. Sampling methods and general requirements as stated in TS 2470 [32] were complied with, and attention was paid to ensure that no rot, knots, cracks, or differences in colour or density were present in the samples. The samples were subjected to natural drying for four months until they reached approximately $12 \%$ moisture content. Then, prior to the densification treatment, the samples were cut in the draft dimensions given in Table 1 .
The samples were placed in a conditioning cabinet prior to densification and held at a relative humidity of $65 \pm 3 \%$ and temperature of $20 \pm 2{ }^{\circ} \mathrm{C}$ until a stable weight was achieved [33]. In order to avoid potential fluctuations in the moisture content, the samples were then put in plastic bags and stored until densification procedures were begun.

\section{Densification and thermal post-treatment}

The samples were thermo-mechanically densified with a hydraulic press machine having a capacity of 180 tons, pressure and temperature control capability, and a pressing tray with dimensions of $60 \times 60 \mathrm{~cm}^{2}$. The process of densification was carried out by applying four variations using two compression ratios (20 and $40 \%$ ) and two temperatures $\left(110 \pm 5\right.$ and $\left.150 \pm 5{ }^{\circ} \mathrm{C}\right)$. The samples, after being placed on the lower tray in the pressing mechanism, were subjected to mild pressure. Heat was transferred to the samples through their contact with the heated upper and lower sections of the press tray and their internal temperature was monitored by a thermometer until the target temperature was reached. Afterwards, the samples were subjected to automatically controlled radial compression (60 $\mathrm{mm} / \mathrm{min}$ loading speed). Metal rods placed at intervals on the pressing tray enabled the samples to achieve the desired $20 \mathrm{~mm}$ thickness. After being kept under pressure for $10 \mathrm{~min}$, the samples were removed from the machine and allowed to cool to room temperature, during which time pressure of approximately $5 \mathrm{~kg} / \mathrm{cm}^{2}$ was applied to minimise any spring-back effects. To provide dimensional stability, the densified pine samples were thermally posttreated at 185 and $212{ }^{\circ} \mathrm{C}$ for $2 \mathrm{~h}$. Thermal post-treatment was carried out under the protection of water vapour according to the process described in the Finnish ThermoWood Handbook [34] after which the densified and thermal-treated samples were cut into smaller samples according to both density and decay test standards.

\section{Density test}

The air-dry density of the samples was determined according to TS 2472 [35]. The samples $(n=6)$ were stored in a conditioning cabin at a temperature of $20 \pm 2{ }^{\circ} \mathrm{C}$ and relative humidity of $65 \pm 3 \%$, until they

Table 1 Dimensions of pine sapwood samples before densification

\begin{tabular}{llll}
\hline Compression ratio $(\%)$ & Length, longitudinal direction $(\mathrm{mm})$ & Width, tangential direction $(\mathrm{mm})$ & Thickness, radial direction $(\mathrm{mm})$ \\
\hline Control & 400 & 60 & 20 \\
20 & 400 & 60 & 25 \\
40 & 400 & 60 & 33.3 \\
\hline
\end{tabular}


reached a stable weight. In this condition, each sample $(M)$ was weighed with a sensitivity of $\pm 0.01 \mathrm{~g}$. Dimensions (length, width, thickness) were measured with a vernier calliper $( \pm 0.01 \mathrm{~mm}$ sensitivity), and the volumes $(V)$ were determined. The air-dry density $(\delta)$ was calculated using Eq. (1).

$\delta\left(\mathrm{g} / \mathrm{cm}^{3}\right)=M / V$

\section{Decay test}

Decay tests were conducted in the Wood Preservation Laboratory of Düzce University according to TS $5563 \mathrm{EN}$ 113 [36]. All test samples $(n=4)$ were dried at $60^{\circ} \mathrm{C}$ for $24 \mathrm{~h}$, weighed $\left(M_{1}\right)$, then sterilized by autoclaving at $100 \pm 2{ }^{\circ} \mathrm{C}$ for $20 \mathrm{~min}$. For the study, one white-rot fungus (Trametes versicolor (L: Fr.) Pilat. (FFPRI 1030)) and one brown-rot fungus (Coniophora puteana (Schum.: Fr.) P. Karst (Mad-15)) were used for determining the decay resistance of the samples. First of all, a 3.7\% malt extract agar (MEA) medium was prepared for the test fungi. Then, treated and control samples were placed in the Petri dishes, with a feeder strip laid across the samples to foster growth of the mycelium on the samples. Following fungal exposure for 12 weeks in an incubator at $25^{\circ} \mathrm{C}$ and $70 \%$ relative humidity, the wood samples were cleaned of the fungal mycelia. All samples were dried at $60{ }^{\circ} \mathrm{C}$ for $24 \mathrm{~h}$ to calculate the percentage of mass loss and then weighed $\left(M_{2}\right)$. The mass losses were calculated using Eq. (2).

Mass loss $(\%)=\left(M_{1}-M_{2}\right) / M_{1} \times 100$

\section{Scanning electron microscopy (SEM) analysis}

Changes in the cell structure of samples exposed to $T$. versicolor were investigated using the FEI Quanta FEG 250 scanning electron microscope. Small wood samples with the dimensions of $8 \times 8 \times 8 \mathrm{~mm}^{3}$ (longitudinal $\times$ tangential $\times$ radial) were prepared for SEM analysis, and the wood sample surfaces were sputter coated with gold. Microscopic images at different magnifications were obtained from tangential and cross-sectional segments of the pine sapwood samples.

\section{Statistical evaluation}

Analysis of variance (ANOVA) tests were performed to determine the effect of densification and thermal posttreatment on the mass loss (in the samples exposed to $T$. versicolor and $C$. puteana) and on the density of the pine sapwood samples (0.05 significance level). Significant differences between the groups were compared using the Duncan test.

\section{Results and discussion}

ANOVA results of mass loss and density measurements of the densified and thermally post-treated pinewood samples are given in Table 2. The effects of densification and thermal treatment on mass loss and density were found to be statistically significant $(P \leq 0.05)$. Duncan test results conducted for multiple comparisons of the means of mass loss and density in densified and thermally post-treated pinewood are shown in Table 3.

\section{Density}

Density of the samples increased after densification treatment depending on the compression ratio and compression temperature. Higher density values were obtained in the samples densified at higher compression ratios and lower compression temperatures. The highest density $(0.914 \mathrm{~g} /$ $\mathrm{cm}^{3}$ ) was found in the samples compressed at the ratio of $40 \%$ at $110{ }^{\circ} \mathrm{C}$, to which no thermal post-treatment was applied. The density of these samples increased at the ratio of $51 \%$ as compared to the control samples (Fig. 1). The density increases occurring after compression resulted from the fact that the samples became volumetrically smaller due to the reduction of their cavity volume. Previous studies showed that increases in density were higher in wood materials compressed at low temperature since the spring-back would be less, thus confirming the results of this study [26, 37]. However, other studies have shown that an increases in compression temperature caused further increase in density [38-42]. In the aforementioned studies, it can be said that the differences in the density increase due to the compression temperature are caused by the applied densification method. In this study and the study performed by Pelit et al. [26, 37], the wood samples were compressed at fixed rates through the use of metal stopping rods during the pressing phase. However, in other studies, wood materials are compressed at constant pressure without using stopping rods.

After thermal post-treatment, the density of both control (undensified) and densified samples decreased. In particular, the density values of both control samples and the samples densified at a low compression ratio (20\%) decreased as a result of the increase in temperature of the thermal treatment. The minimum density value $(0.550 \mathrm{~g} /$ $\mathrm{cm}^{3}$ ) was identified in the undensified samples thermally treated at $212{ }^{\circ} \mathrm{C}$. In the samples densified at the high compression ratio $(40 \%)$, an increase of the thermal posttreatment temperature influenced density values positively (Table 3; Fig. 1). In the literature, it has been reported that thermal treatments at high temperature applied to densified wood significantly reduced the spring-back or set-recovery 
Table 2 ANOVA (analysis of variance) results for mass loss and density

\begin{tabular}{|c|c|c|c|c|c|c|}
\hline \multirow[t]{2}{*}{ Factors } & \multicolumn{2}{|l|}{ Density } & \multicolumn{2}{|c|}{ Mass loss for $T$. versicolor } & \multicolumn{2}{|c|}{ Mass loss for $C$. puteana } \\
\hline & $F$ ratio & $p$ value & $F$ ratio & $p$ value & $F$ ratio & $p$ value \\
\hline Densification & 467.8671 & $0.0000 *$ & 9.4621 & $0.0000 *$ & 6.4608 & $0.0003^{*}$ \\
\hline Thermal treatment & 19.3745 & $0.0000^{*}$ & 169.5726 & $0.0000^{*}$ & 557.1379 & $0.0000^{*}$ \\
\hline Densification $\times$ thermal treatment & 1.4190 & 0.2026 & 2.7304 & $0.0152 *$ & 4.1866 & $0.0008^{*}$ \\
\hline
\end{tabular}

$F$ ratio: test statistic; $p$ value: level of significance

* Significant at $95 \%$ confidence level $(p \leq 0.05)$

Table 3 The mean values of density and mass loss (T. versicolor and C. puteana-initiated) in densified and thermally post-treated pine sapwood samples

\begin{tabular}{|c|c|c|c|c|}
\hline \multirow[t]{2}{*}{ Densification } & \multirow{2}{*}{$\begin{array}{l}\text { Thermal } \\
\text { treatment }\end{array}$} & \multirow{2}{*}{$\begin{array}{l}\text { Density }\left(20^{\circ} \mathrm{C}, \mathrm{RH}\right. \\
65 \%)\left(\mathrm{g} / \mathrm{cm}^{3}\right)\end{array}$} & \multicolumn{2}{|l|}{ Mass loss (\%) } \\
\hline & & & T. versicolor & C. puteana \\
\hline \multirow[t]{3}{*}{ Undensified } & Untreated & $0.604 \mathrm{~F}^{*}(0.007)$ & $31.32 \mathrm{~A}(3.93)$ & $24.90 \mathrm{~A}(2.26)$ \\
\hline & $185^{\circ} \mathrm{C}$ & $0.579 \mathrm{FG}(0.027)$ & $19.38 \mathrm{BC}(2.49)$ & $11.63 \mathrm{D}(1.18)$ \\
\hline & $212^{\circ} \mathrm{C}$ & $0.550 \mathrm{G}(0.021)$ & $6.72 \mathrm{E}(1.61)$ & 7.80 E $(0.29)$ \\
\hline \multirow[t]{3}{*}{$110{ }^{\circ} \mathrm{C} / 20 \%$} & Untreated & 0.735 C (0.009) & $28.41 \mathrm{~A}(4.32)$ & $23.23 \mathrm{AB}(1.53)$ \\
\hline & $185^{\circ} \mathrm{C}$ & $0.708 \mathrm{CD}(0.019)$ & 20.27 B (4.69) & $11.73 \mathrm{D}(1.36)$ \\
\hline & $212^{\circ} \mathrm{C}$ & $0.689 \mathrm{DE}(0.008)$ & $7.56 \mathrm{E}(1.54)$ & $7.62 \mathrm{E}(0.50)$ \\
\hline \multirow[t]{3}{*}{$110{ }^{\circ} \mathrm{C} / 40 \%$} & Untreated & 0.914 A $(0.013)$ & 20.65 B (5.72) & $23.12 \mathrm{AB}(4.45)$ \\
\hline & $185^{\circ} \mathrm{C}$ & 0.874 B (0.037) & $15.43 \mathrm{CD}(2.04)$ & $10.32 \mathrm{D}(0.66)$ \\
\hline & $212^{\circ} \mathrm{C}$ & $0.889 \mathrm{AB}(0.040)$ & $6.87 \mathrm{E}(1.65)$ & $7.28 \mathrm{E}(0.17)$ \\
\hline \multirow[t]{3}{*}{$150{ }^{\circ} \mathrm{C} / 20 \%$} & Untreated & $0.712 \mathrm{CD}(0.031)$ & $27.08 \mathrm{~A}(4.45)$ & $22.32 \mathrm{~B}(2.72)$ \\
\hline & $185^{\circ} \mathrm{C}$ & $0.694 \mathrm{D}(0.031)$ & $17.39 \mathrm{BCD}(4.34)$ & $10.30 \mathrm{D}(1.16)$ \\
\hline & $212{ }^{\circ} \mathrm{C}$ & 0.654 E (0.009) & $6.56 \mathrm{E}(3.87)$ & $7.06 \mathrm{E}(0.53)$ \\
\hline \multirow[t]{3}{*}{$150{ }^{\circ} \mathrm{C} / 40 \%$} & Untreated & 0.873 B $(0.024)$ & $18.42 \mathrm{BC}(2.99)$ & $17.68 \mathrm{C}(2.45)$ \\
\hline & $185^{\circ} \mathrm{C}$ & 0.854 B $(0.038)$ & $13.50 \mathrm{D}(3.77)$ & $10.65 \mathrm{D}(1.26)$ \\
\hline & $212{ }^{\circ} \mathrm{C}$ & 0.855 B (0.028) & $6.05 \mathrm{E}(1.88)$ & 7.46 E (0.29) \\
\hline
\end{tabular}

Values in parenthesis are standard deviations

* Homogeneity groups: same letters in each column indicate that there is no statistical difference between the samples according to the Duncan's multiply range test

Fig. 1 Density changes in densified and thermally posttreated pinewood samples

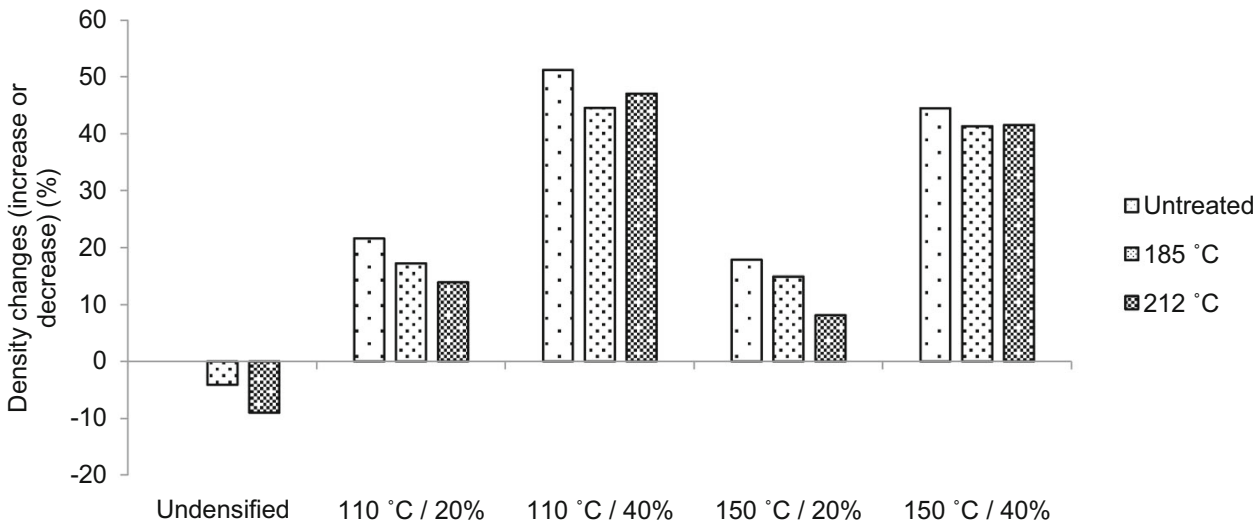


effect [20-22, 25, 29-31, 43, 44]. After thermal posttreatment, density increases in the pine samples densified at a high compression rate can be explained with the reported literature.

\section{Decay resistance}

The maximum mass loss $(31.32 \%)$ in the pinewood samples exposed to $T$. versicolor was found in the undensified samples without thermal post-treatment. However, no statistical difference was observed between the mass loss in these samples and in the samples densified at a low (20\%) compression rate (Table 3 ). The mass loss in the samples compressed at a high ratio $(40 \%)$ was lower as well. An increase in the compression ratio caused the mass loss in the samples exposed to $T$. versicolor to decrease. Compression temperature had no significant effect on mass loss (Table 3). It was reported in study performed by Skyba et al. [45] that mass loss in the THM-densified samples were at a minimum level after the white-rot fungi test; however, the samples did not exhibit any improved resistance to the decay fungi as a result of the THM treatment. In addition, in previous studies on wood densification performed with different methods [i.e., thermo-mechanical (TM), THM, VTC] it was expressed that the densification process applied to various wood materials did not provide any protection against fungal decay [30, 40, 46, 47]. It was determined by SEM analysis that the destruction of the cell wall caused by T. versicolor in the highly compressed samples (Fig. 2c) was less than that of the control (Fig. 2a) samples. The fact that void volume (porosity) of the highly compressed samples was lower and their cell lumens were partially closed might have prevented $T$. versicolor from penetrating and growing in the cell. SEM analysis (Fig. 3) had confirmed this situation. Compared with the control samples (Fig. 3a), the hyphal extensions in tracheids and pits causing the decay were seen much less frequent in compressed samples (Fig. 3c). Similar findings were reported by Schwarze and Spycher [48], Skyba et al. [45], and Dubey [49]. In addition, the lowered porosity of the compressed wood, may have reduced the oxygen content necessary for the fungi to develop in the cells inhibited their activity [50]. Furthermore, according to SEM images (Fig. 2a, c), it was observed that cell wall destruction caused by $T$. versicolor occurred particularly in the earlywood region of the pine samples. In addition, the spring-back in the densified samples without thermal post-treatment stemmed from the relative humidity in their cell structure that occurred during the test and increased the void volume (porosity) of the samples (Fig. 2c). After thermal post-treatment, the mass loss in the samples exposed to $T$. versicolor were lower and the biological resistance of the samples increased significantly, depending on the increase in the treatment temperature. The minimum mass loss was obtained in the thermally posttreated samples at $212{ }^{\circ} \mathrm{C}$ (Table 3). T. versicolor-initiated destruction of the cell wall scarcely occurred in the samples thermally post-treated at $212{ }^{\circ} \mathrm{C}$ (Fig. 2b, d). Particularly in densified and thermally post-treated samples, it has been seen that the cell spaces and resin canal which allow the hyphal extensions to spread to the inner parts of the wood are almost completely closed (Fig. 2d). In addition, the analyses of tangential section of these samples show that the hyphal extensions in the tracheids have almost never occurred (Fig. 3d). Moreover, the statistical analysis showed that the densification processes had no significant effect on the mass loss of the samples thermally post-treated at $212{ }^{\circ} \mathrm{C}$ and exposed to T. versicolor (Table 3).

After the $C$. puteana test, the highest mass loss $(24.90 \%)$ was found in the control (undensified and without thermal treatment) samples. The densification process led to a slight decrease in $C$. puteana-originated mass loss. The effect of compression temperature on the existing mass loss was found to be more significant as compared to that of compression ratio (Table 3). After the $C$. puteana test, less mass loss resulted in the samples densified at the higher temperature $\left(150^{\circ} \mathrm{C}\right)$. In the thermally treated samples, $C$. puteana-originated mass loss was significantly decreased depending on increase in the treatment temperature. The minimum mass change measured after the tests was found in the samples thermally treated at $212{ }^{\circ} \mathrm{C}$, as in the case of the $T$. versicolor test (Table 3 ). In previous studies, it was revealed that thermal treatment applied to wood at temperatures of $200{ }^{\circ} \mathrm{C}$ and over significantly decreased fungioriginated mass loss. It was also reported that decrease in mass loss was caused by the degradation of hemicellulose and cellulose, the main components of wood, and the condensation of lignin [51, 52]. Furthermore, the presence of moisture in the wood is necessary for the fungi to develop. Thus, as a result of the lowered values on the hygroscopicity index after thermal treatment, increased decay resistance has been observed in thermally treated wood [12]. C. puteana-originated mass loss significantly decreased in the densified and thermally post-treated samples at two different temperatures (185 and $212{ }^{\circ} \mathrm{C}$ ). However, it was determined that the densification treatments had no impact on the increase of biological resistance in the samples thermally post-treated at either 185 or $212{ }^{\circ} \mathrm{C}$. In other words, no statistically significant difference was found between the mass loss measured in the densified and thermally post-treated samples and in that measured in the undensified and thermally treated samples at the same temperature (Table 3). Bami and Mohebby [50] reported that results of soft-rot and brown-rot decay tests on combined hydro-thermo-mechanically modified (CHTM) poplar indicated increased fungal bioresistance; 

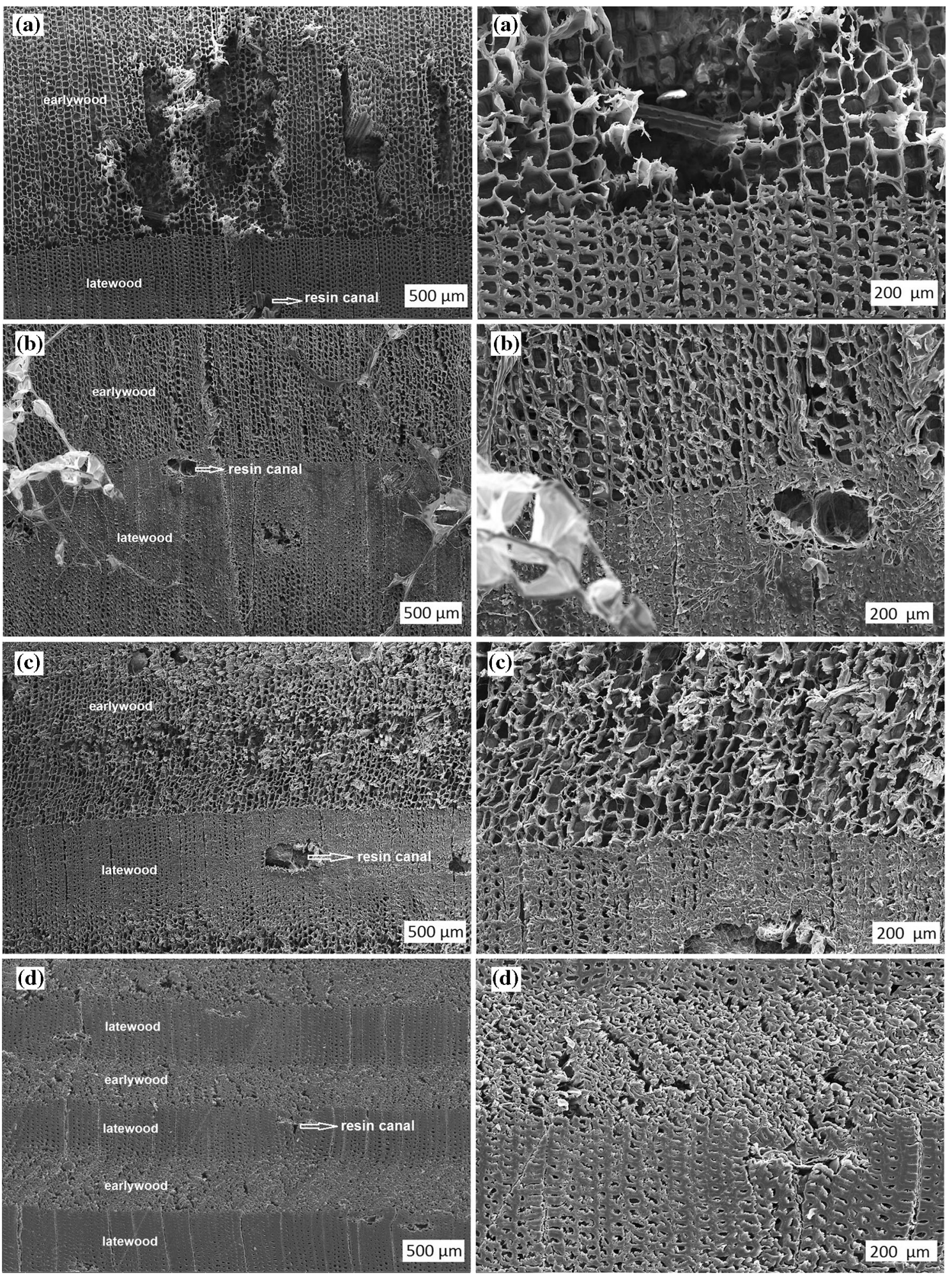

Fig. 2 SEM images of cross sections of pinewood samples exposed to T. versicolor: a control (undensified and without thermal treatment), b only thermally post-treated at $212{ }^{\circ} \mathrm{C}$, c only $40 \%$ compressed at $110{ }^{\circ} \mathrm{C}$, d $40 \%$ compressed at $110{ }^{\circ} \mathrm{C}$ and thermally post-treated at $212{ }^{\circ} \mathrm{C}$

however, the hydrothermal treatment step played a much more important role in the increased bioresistance and reduction of fungal attack. In another study it was reported that resistance against fungal decay and soft-rotting microorganisms increased in the Norway spruce samples to which thermo-mechanical densification and oil-heat 

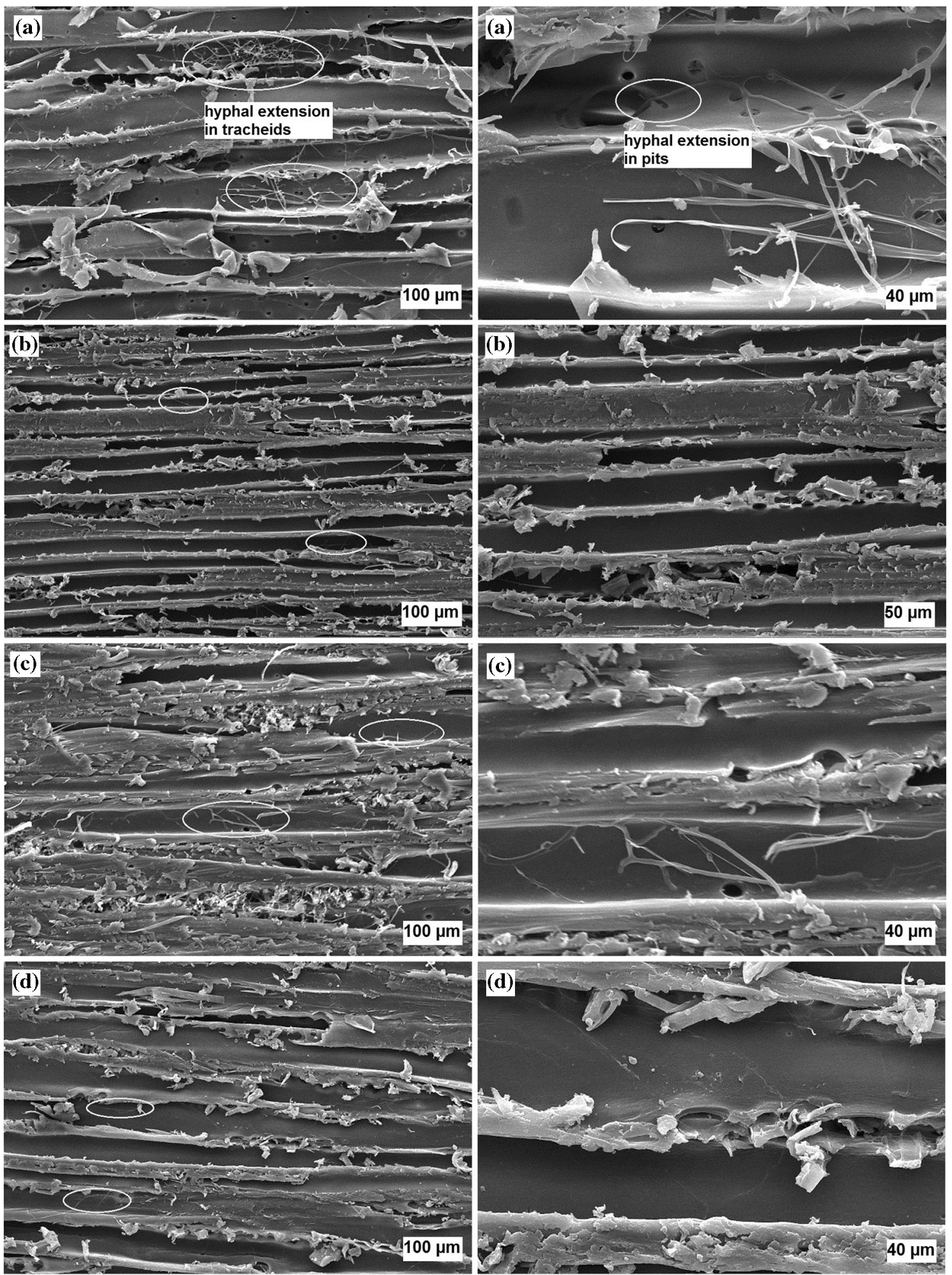

Fig. 3 SEM images of tangential sections of pinewood samples exposed to T. versicolor: a control (undensified and without thermal treatment), b only thermally post-treated at $212{ }^{\circ} \mathrm{C}$, c only $40 \%$ compressed at $110{ }^{\circ} \mathrm{C}$, d $40 \%$ compressed at $110{ }^{\circ} \mathrm{C}$ and thermally post-treated at $212{ }^{\circ} \mathrm{C}$ 
treatment were applied, either separately or together, and the best results were achieved in the samples in which both densification and oil-heat treatment were applied together [53].

\section{Conclusions}

Density of pine sapwood samples increased in parallel with increase in the compression ratio. Regarding compression temperature, higher density was obtained in the samples compressed at $110{ }^{\circ} \mathrm{C}$. After thermal post-treatment, the density decreased in all samples depending on the treatment temperature.

Mass loss was occurred in the samples exposed to $T$. versicolor and $C$. puteana, depending on densification and thermal post-treatment conditions. The highest mass loss was seen in the control samples. Less T. versicolor-originated mass loss resulted in the samples compressed at the higher ratio (40\%), while less C. puteana-originated mass loss resulted in the samples compressed at the higher temperature $\left(150{ }^{\circ} \mathrm{C}\right)$. The mass loss was reduced in the samples exposed to both decay fungi dependent on the increase in temperature of the thermal post-treatment. Decay resistance significantly increased, especially in the samples at $212{ }^{\circ} \mathrm{C}$. The effect of the densification conditions on the increase in decay resistance of the thermally post-treated samples was insignificant.

The SEM analyses showed that the destruction of the cell wall caused by $T$. versicolor occurred mostly in the earlywood region and did not affect the latewood region as much. In the samples without thermal post-treatment, hyphal extensions in tracheids and destruction of the cell wall were more severe in the control samples as compared to the samples compressed at the high ratio (40\%). Moreover, hyphal extensions and destruction of the cell wall were not observed almost in the thermally post-treated samples.

\section{References}

1. Skyba O, Niemz P, Schwarze FW (2008) Degradation of thermohygro-mechanically (THM)-densified wood by soft-rot fungi. Holzforschung 62:277-283

2. Paes JB, Morais VM, de Lima CR (2004) Natural resistance of nine woods of Brasilian semi-arid region to wood-destroying fungi under laboratory conditions. Rev Arvore 28:275-282

3. Kartal NS, Hwang WJ, Imamura Y, Sekine Y (2006) Effect of essential oil compounds and plant extracts on decay and termite resistance of wood. Holz Roh Werkst 64:455-461

4. Cao Y, Lu J, Huang R, Zhao Y, Wu Y (2011) Evaluation of decay resistance for steam-heat-treated wood. BioResources 6:4696-4704

5. Esteves B, Pereira H (2009) Wood modification by heat treatment: review. BioResources 4:370-404
6. Viitaniemi P, Jämsä S, Koskela K, Paajanen L, Vuorinen T, Maunu S, Paakkari T (2002) Reaction mechanisms of modified wood. Finnish forest cluster research programme wood wisdom (1998-2001). In: Paavilainen L (ed) Final report, Helsinki, pp 185-192

7. Homan W, Tjeerdsma B, Beckers E, Jorissen A (2000) Structural and other properties of modified wood. In: World conference on timber engineering, Whistler

8. González-Peña M, Breese M, Hill C (2004) Hygroscopicity in heat-treated wood: effect of extractives. In: International conference on environmentally compatible forest products (ICECFOP), Leicester, pp 105-119

9. Hakkou M, Pétrissans M, Zoulalian A, Gérardin P (2005) Investigation of wood wettability changes during heat treatment on the basis of chemical analysis. Polym Degrad Stab 89:1-5

10. Korkut S, Kocaefe D (2009) Effect of heat treatment on wood properties. Düzce Univ J For 5:11-34

11. Kamdem DP, Pizzi A, Jermannaud A (2002) Durability of heat treated wood. Holz Roh Werkst 60:1-6

12. Lekounougou S, Kocaefe D (2014) Durability of thermally modified Pinus banksiana (Jack pine) wood against brown and white rot fungi. Int Wood Prod J 5:92-97

13. Yalçın M, Şahin Hİ (2015) Changes in the chemical structure and decay resistance of heat-treated narrow-leaved ash wood. Maderas Cienc Technol 17:435-446

14. Yıldız S, Gezer ED, Yıdız ÜC (2006) Mechanical and chemical behavior of spruce wood modified by heat. Build Environ 41:1762-1766

15. Boonstra MJ, Van Acker J, Tjeerdsma BF, Kegel EV (2007) Strength properties of thermally modified softwoods and its relation to polymeric structural wood constituents. Ann For Sci 64:679-690

16. Korkut S, Kök MS, Korkut DS, Gürleyen T (2008) The effects of heat treatment on technological properties in red-bud maple (Acer trautvetteri Medw.) wood. Bioresour Technol 99:1538-1543

17. Guo F, Huang R, Lu J, Chen Z, Cao Y (2014) Evaluating the effect of heat treating temperature and duration on selected wood properties using comprehensive cluster analysis. J Wood Sci 60:255-262

18. Boonstra MJ (2008) A two-stage thermal modification of wood. $\mathrm{PhD}$ dissertation in co-supervision by Ghent University and Université Henry Poincaré, Nancy

19. Inoue M, Norimoto M, Tanahashi M, Rowell RM (1993) Steam or heat fixation of compressed wood. Wood Fiber Sci 25:224-235

20. Navi P, Heger F (2004) Combined densification and thermo-hydro-mechanical processing of wood. MRS Bull 29:332-336

21. Kutnar A, Kamke FA (2012) Influence of temperature and steam environment on set recovery of compressive deformation of wood. Wood Sci Technol 46:953-964

22. Laine K, Rautkari L, Hughes M, Kutnar A (2013) Reducing the set-recovery of surface densified solid Scots pine wood by hydrothermal post-treatment. Eur J Wood Wood Prod 71:17-23

23. Morsing N (2000) Densification of wood-the influence of hygrothermal treatment on compression of beech perpendicular to the grain. Ph.D. dissertation, Department of Structural Engineering and Materials, Technical University of Denmark, Lyngby

24. Boonstra MJ, Blomberg J (2007) Semi-isostatic densification of heat-treated radiata pine. Wood Sci Technol 41:607-617

25. Pařil $P, B$ rabec M, Maňák O, Rousek R, Rademacher P, Čermák P, Dejmal A (2014) Comparison of selected physical and mechanical properties of densified beech wood plasticized by ammonia and saturated steam. Eur J Wood Wood Prod 72:583-591

26. Pelit H, Sönmez A, Budakçı M (2014) Effects of ThermoWood ${ }^{\circledR}$ process combined with thermo-mechanical densification on some physical properties of Scots pine (Pinus sylvestris L.). BioResources 9:4552-4567 
27. Navi P, Girardet F (2000) Effects of thermo-hydro-mechanical treatment on the structure and properties of wood. Holzforschung 54:287-293

28. Kamke FA, Sizemore H (2008) Viscoelastic thermal compression of wood. US Patent No. US7404422B2

29. Dwianto W, Inoue M, Norimoto M (1997) Fixation of compressive deformation of wood by heat treatment. J Jpn Wood Res Soc (Nippon Mokuzai Gakki) 43:303-309

30. Welzbacher CR, Wehsener J, Rapp AO, Haller P (2008) Thermomechanical densification combined with thermal modification of Norway spruce (Picea abies Karst) in industrial scale-dimensional stability and durability aspects. Holz Roh Werkst 66:39-49

31. Fang CH, Cloutier A, Blanchet P, Koubaa A, Mariotti N (2011) Densification of wood veneers combined with oil-heat treatment, part 1: dimensional stability. BioResources 6:373-385

32. TS 2470 (1976) Sampling methods and general requirements for physical and mechanical tests in wood. Turkish Standards Institution, Ankara

33. TS 2471 (1976) Determination of moisture content for physical and mechanical tests in wood. Turkish Standards Institution, Ankara

34. Finnish Thermowood Association (2003) ThermoWood handbook. Finnish Thermowood Association, Helsinki

35. TS 2472 (1976) Determination of density for physical and mechanical tests in wood. Turkish Standards Institution, Ankara

36. TS 5563 EN 113 (1996) Wood preservatives-determination of the toxic values against wood destroying basidiomycetes cultured on an agar medium. Turkish Standard Institution, Ankara

37. Pelit H, Sönmez A, Budakçı M (2015) Effects of thermomechanical densification and heat treatment on density and Brinell hardness of Scots pine (Pinus sylvestris L.) and Eastern beech (Fagus orientalis L.). BioResources 10:3097-3111

38. Tabarsa T, Chui YH (1997) Effects of hot-pressing on properties of white spruce. Forest Prod J 47:71-76

39. Ünsal Ö, Candan Z (2008) Moisture content, vertical density profile and Janka hardness of thermally compressed pine wood panels as afunction of press pressure and temperature. Dry Technol 26:1165-1169

40. Ünsal Ö, Kartal SN, Candan Z, Arango RA, Clausen CA, Green F (2009) Decay and termite resistance, water absorption and swelling of thermally compressed wood panels. Int Biodeterior Biodegrad 63:548-552

41. Fang CH, Mariotti N, Cloutier A, Koubaa A, Blanchet P (2012) Densification of wood veneers by compression combined with heat and steam. Eur J Wood Wood Prod 70:155-163
42. Bekhta P, Proszyk S, Krystofiak T, Sedliacik J, Novak I, Mamonova M (2015) Effects of short-term thermomechanical densification on the structure and properties of wood veneers. Wood Mater Sci Eng 12:40-54

43. Cai J, Ding T, Yang L (2012) Dimensional stability of poplar wood after densification combined with heat treatment. Appl Mech Mater 152-154:112-116

44. Pelit H, Budakçı M, Sönmez A (2016) Effects of heat posttreatment on dimensional stability and water absorption behaviours of mechanically densified Uludağ fir and black poplar woods. BioResources 11:3215-3229

45. Skyba O, Niemz P, Schwarze FW (2009) Resistance of thermohygro-mechanically (THM) densified wood to degradation by white rot fungi. Holzforschung 63:639-646

46. Kutnar A, Humar M, Kamke FA, Sernek M (2011) Fungal decay of viscoelastic thermal compressed (VTC) wood. Eur J Wood Wood Prod 69:325-328

47. Lesar B, Humar M, Kamke FA, Kutnar A (2013) Influence of the thermo-hydro-mechanical treatments of wood on the performance against wood-degrading fungi. Wood Sci Technol 47:977-992

48. Schwarze FW, Spycher M (2005) Resistance of thermohygromechanically densified wood to colonisation and degradation by brown-rot fungi. Holzforschung 59:358-363

49. Sundqvist B (2004) Colour changes and acid formation in wood during heating. Ph.D. dissertation, Lulea University of Technology, Lulea

50. Tümen İ, Aydemir D, Gündüz G, Üner B, Çetin H (2010) Changes in the chemical structure of thermally treated wood. BioResources 5:1936-1944

51. Welzbacher CR, Rapp AO, Haller P, Wehsener J (2007) Biological and mechanical properties of densified and thermally modified Norway spruce. In: Sustainability of constructions integrated approach to life-time structural engineering. Proceedings of the first workshop, Lisbon

52. Bami LK, Mohebby B (2011) Bioresistance of poplar wood compressed by combined hydro-thermo-mechanical wood modification (CHTM): soft rot and brown-rot. Int Biodeterior Biodegrad 65:866-870

53. Dubey MK (2010) Improvements in stability, durability and mechanical properties of radiata pine wood after heat-treatment in a vegetable oil. Ph.D. dissertation, University of Canterbury, Christchurch 